\title{
Malignancy and Complication Rate in Reoperation of Recurrent Goiter
}

\author{
Nüks Guatr Nedeni ile Yapılan Operasyonlarda Malignansi ve Komplikasyon Sıklığı
}

\author{
Halise Çınar Yavuz ${ }^{1}$, Türkan Mete ${ }^{1}$, Leyla Irak ${ }^{1}$, Yusuf Aydin ${ }^{2}$, Hüseyin Demirci ${ }^{3}$, Serdar Güler ${ }^{1}$
}

\footnotetext{
${ }^{1}$ Ministry of Health, Ankara Numune Training and Research Hospital Department of Endocrinology and Metabolism, Ankara, Turkey

${ }^{1}$ Ministry of Health, Ankara Numune Training and Research Hospital Department of Endocrinology and
${ }^{2}$ Duzce University, Faculty of Medicine, Department of Endocrinology and Metabolism, Ankara, Turkey

${ }^{3}$ Turgut Ozal Faculty of Medicine, Department of Endocrinology and Metabolism, Ankara, Turkey
}

\section{ABSTRACT}

Objective: The aim of this study was to evaluate the fine needle aspiration biopsy findings of recurrent goiter patients who were operated subtotally or lobectomised for benign causes, and to determine the malignancy and complication rates for those who were reoperated.

Methods: Between 2008 and 2009, 114 patients diagnosed with recurrent goiter were involved in this study. The cytological findings of 158 nodules and histological findings of 18 patients with reoperation were examined. The complications of primary surgery and reoperation of recurrent goiter were determined.

Results: The operation indications were euthyroid multinodular goiter in 106 of the patients and toxic multinodular goiter in 8 of them. The average time elapsed from the time of the first operation was $16.5 \pm 7.5$ years. The patients with a fine needle aspiration biopsy resulted in 6 with suspicion of malignancy, 3 with malignancy, 5 with hurtle cell cytology, 7 with cellular microfollicular lesion, 1 patient with toxic multinodular goiter and 2 with inadequate cellular cytology; a total of 24 patients $(21 \%)$ were asked for reoperation. Among the 18 patients who accepted reoperation, pathology results discovered 2 papillary microcarcinomas and 2 papillary thyroid carcinomas. A total of 7 of the 18 patients with reoperation had surgical complications: 3 had vocal cord paralysis and 4 had hypoparathyroidism.

Conclusion: In our study, we found that a high rate of recurrent goiter patients required reoperation and there was a considerable amount of complication rate of reoperative thyroid surgery. To eliminate the potential risk of reoperation, we recommend a total thyroidectomy instead of subtotal thyroidectomy or lobectomy as the surgery of choice for the primary surgery with benign indications.

Key Words: Recurrent goiter, thyroid malignancy, thyroidectomy complications, papillary thyroid carcinoma

Received: 09.20.2015
Accepted: 10.14 .2015

\section{ÖZET}

Amaç: Bu çalışmanın amacı, benign nedenlerle subtotal tiroidektomi veya lobektomi yapılmış nüks guatrı olan hastaların ince iğne aspirasyon biyopsi bulgularını değerlendirmek ve yeniden opere edilenlerdeki malignite ve komplikasyon sıklığını belirlemektir.

Gereç ve Yöntem: 2008 ve 2009 yılları arasında, nüks guatrı olan 114 hasta çalışmaya dahil edildi. 158 nodülün sitolojik bulguları ve yeniden opere edilen 18 hastaya ait histolojik bulgular incelendi. Illk cerrahiye bağlı gelişen komplikasyonlar ve nüks guatr nedeni ile yapılan operasyona bağı gelişen komplikasyonlar belirlendi.

Bulgular: Çalışmaya dahil edilen hastaların 106'sı ötiroid multinodüler guatr, $8^{\prime}$ i toksik multinodüler guatr nedeni ile opere olmuştu. İlk operasyondan bu yana geçen süre ortalama $16,5 \pm 7,5$ yıldı. İnce iğne aspirasyon biyopsisi sonucu malignite şüphesi gelen 6 , malignite gelen 3 , hurthle hücreli lezyon gelen 5 , selüler mikrofolliküler lezyon gelen 7 , yetersiz sitoloji sonucu olan 2 ve toksik multinodüler guatrı olan 1 hasta; toplam 24 hastaya (\%21) yeniden operasyon önerildi. Yeniden operasyonu kabul eden 18 hastanın 2'sinde papiller mikrokarsinom ve 2'sinde papiller tiroid karsinomu saptandı. Yeniden opere edilen 18 hastanın 7'sinde cerrahiye bağlı komplikasyonlar gelişti: 3 hastada vokal kord paralizisi ve 4 hastada hipoparatiroidi.

Sonuç: Çalışmamızda, nüks guatrı olan hastalarda yüksek oranda yeniden operasyon gereksinimi olduğunu ve yeniden yapılan tiroid cerrahisinin önemli miktarda komplikasyon ile ilişkili olduğunu bulduk. Yeniden operasyona bağlı gelişebilecek potansiyel riskleri önlemek için, benign nedenlerle yapılan primer cerrahide subtotal tiroidektomi veya lobektomi yerine total tiroidektominin seçilmesini önermekteyiz.

Anahtar Sözcükler: Nüks guatr, tiroid malignitesi, tiroidektomi komplikasyonları, papiller tiroid karsinomu

Geliş Tarihi: 20.09.2015

Kabul Tarihi: 14.10.2015

Address for Correspondence / Yazışma Adresi: Turkan Mete MD, Ministry of Health, Ankara Numune Training and Research Hospital Department of Endocrinology and Metabolism, Ankara, Turkey E-mail: turkanmete@yahoo.com

(CTelif Hakkı 2016 Gazi Üniversitesi Tıp Fakültesi - Makale metnine http://medicaljournal.gazi.edu.tr/ web adresinden ulaşılabilir. (c) Copyright 2016 by Gazi University Medical Faculty - Available on-line at web site http://medicaljournal.gazi.edu.tr/ doi:http://dx.doi.org/10.12996/gmj.2016.05 
Benign multinodular goiter is one of the most common endocrine surgical problems, effecting $5-7 \%$ of the world's population and mostly relate to iodide deficiency (1-2). Indications for surgery are the presence of obstructive symptoms, thyrotoxicosis, cosmetic concerns or the finding of either malignancy or atypical changes on fine needle aspiration biopsy (FNAB). It is known that $10-15 \%$ of these patients had been operated for thyroid with different causes (3). Reoperation of recurrent goiter comprises $12 \%$ of all operations of the thyroid (4-5). The appropriate surgical procedure for benign multinodular to prevent recurrent goiters is debated.

Total thyroidectomy, rather than bilateral subtotal thyroidectomy, is now accepted as the preferred management for bilateral benign multinodular goiter (MNG) due to the lower complication rates attained by more experienced surgeons, as well as the lower reported recurrence rates when compared with unilateral or subtotal resection (6-10). But recent studies have shown that patients with unilateral resections had fewer post-operative complications than those who had bilateral resections, and the risk of permanent complications was similar. The risk of recurrent goiter was also similar after either operation (11).

There are few studies showing malignancy rates after reoperation of recurrent goiters that were previously operated for benign causes. The aim of this study was to evaluate FNAB findings of patients with recurrent goiter who were operated for benign causes, and to determine malignancy and complication rates among patients who were reoperated.

\section{PATIENTS AND METHODS}

A total of 114 patients attending Ankara Numune Research Hospital Endocrinology outpatient clinic in 2008-2009 with recurrent goiter, who were operated for benign cause, were enrolled in this study. The age of patients, FNAB findings, pathological diagnosis of primary and second surgery, complications of primary and second surgery, presence of levothyroxine replacement and the dosage of replacement were recorded. The study complied with the Helsinki Declaration and was approved by the local research ethics committee. All subjects gave written informed consent.

Thyroid ultrasonography of patients was performed by an endocrinology specialist in the Endocrinology and Metabolism Clinic of Ankara Numune Research and Education Hospital, using a General Electric LOGIQ 3 Expert ultrasonography device and an $11 \mathrm{MHz}$ linear probe. Thyroid volume was calculated according to the ellipsoid method (Brown MC et al., 1978) as: right lobe $(a \times b \times c) \mathrm{ml} \times 0.524$ ] + [left lobe $(a \times b \times c) \mathrm{ml} \times 0.524$ ]. The presence of thyroid nodules was noted. Based on ultrasonographic features, the thyroid gland was classified as homogenous, heterogeneous (irregular increase in echogenicity) and nodular (solitary, multinodular). Subjects with solitary or multiple nodules were defined as nodular goiter.

Fine needle aspirations (FNA) were performed on nodules $\geq 10 \mathrm{~mm}$ in diameter and on 5-10 mm nodules with malignant properties. Biopsy was performed on all nodules of the patients with multiple nodules. Specimens were evaluated by pathologists in the Pathology Department of Ankara Numune Research and Education Hospital, according to Bethesda classification 2007. Results were recorded as inadequate, benign, atypia of undetermined significance or follicular lesion of undetermined significance, follicular neoplasm or suspicious for a follicular neoplasm, suspicious for malignancy and malignancy.

All patients were given serum TSH, free T3 (fT3), free T4 (fT4) tests as well as thyroid ultrasounds. Blood samples were taken in biochemistry tubes for TSH, fT3, fT4 tests and analyzed at the biochemistry laboratory of Ankara Numune Research and Education Hospital. In our hospital, TSH, fT3 and fT4 tests were performed by a UniCel Dxl 800 autoanalyzer using Access HYPERsensitive human TSH, Access fT3, Access fT4, (Beckman Coulter, Ireland) kits with the chemiluminescence method. Reference ranges for thyroid tests were $0.34-4.25 \mu \mathrm{lU} / \mathrm{ml}$ for TSH, $2.5-3.9 \mathrm{pg} / \mathrm{ml}$ for fT3 and 0.61$1.2 \mathrm{ng} / \mathrm{dl}$ for fT4.

The statistical analyses of the data were performed using Statistical Program for Social Sciences (SPSS, Inc., Chicago, IL, USA) version 13 for Windows. Continuous variables were expressed as mean \pm standard deviation (SD) or median (minimum-maximum), whereas categorical variables were expressed as number of observations or percentages. The differences between the groups in terms of measured parameters were analyzed using a Mann-Whitney $U$ test. Chi square tests or Fisher's exact tests were used for the comparisons of categorical variables. The risk factors significantly affecting malignancy according to the univariate analysis were analyzed using multivariate logistic regression analysis. A $p$ value of $>0.05$ was considered statistically significant.
Among 114 patients with recurrent goiter, 106 were women and 8 were men; the mean age was $49.2 \pm 12.1$ years, and 47 (41.2\%) of them were taking levothyroxine. The mean of elapsed time from primary surgery was $16.5 \pm 7.5$ years. The indications of primary surgery were multinodular goiter for 106 patients and toxic multinodular goiter for 8 . The primary surgery was subtotal thyroidectomy for 101 and lobectomy for 13. The demographic features are summarized in Table 1 . The complications after primary surgery were hypoparathyroidism for 5 patients and the vocal cord paralysis for 3 .

A total of 221 FNAB were done to 158 nodules of 114 patients with recurrent goiter. FNAB findings were benign in $148(74 \%)$, inadequate in 52 $(26 \%)$, suspicious in $6(2.7 \%)$, Hurthle cell lesion in $5(2.26 \%)$, cellular microfollicular lesion in $7(3.16 \%)$ and papillary thyroid cancer in $3(1.35 \%)$. The FNAB findings are summarized in Table 2 . Of the 158 nodules, 38 were $<1 \mathrm{~cm}$. One nodule with suspicious cytology and one with hurtle cell lesion were $<1 \mathrm{~cm}$. Two nodules with papillary thyroid cancer cytology were $>1 \mathrm{~cm}$.

Operation is recommended for $24(22 \%)$ patients: 6 with suspicious cytology, 3 with malign cytology, 5 with Hurthle cell lesion, 7 with cellular microfollicular lesion, 1 with toxic multinodular goiter and 2 patients with 2 repeat inadequate FNAB findings. Pathological findings of 18 patients who accepted operation included 4 papillary thyroid carcinomas (2 papillary microcarcinomas and 2 papillary carcinomas), 10 nodular hyperplasia, and 1 patient with Hashimoto thyroiditis and 3 with nodular hyperplasia with Hashimoto thyroiditis (Table 3 ). Malignancy was found in $22 \%$ of patients who were reoperated. The malignancy rate was found to be $3.4 \%$ of 114 patients with recurrent goiter. The complications after second surgery were hypoparathyroidism for 4 patients and recurrent laryngeal nerve palsy for 3 . The rate of complications in second surgery was $38 \%$.

Table 1. Demographic features of patients with recurrent goiter.

\begin{tabular}{|c|c|}
\hline Male/Female & $8 / 106$ \\
\hline Age (years) & $49,2 \pm 12,1(26-82)$ \\
\hline Time lapsed from primary surgery (years) & $16,5 \pm 7,5$ years $(4-35)$ \\
\hline $\begin{array}{l}\text { Operation indication of first surgery } \\
\text { (MNG/toxic MNG ) }\end{array}$ & $106 / 8$ \\
\hline Surgical procedure (subtotal/lobectomy) & $101 / 13$ \\
\hline $\begin{array}{l}\text { Levothyroxine replacement treatment } \\
\text { (number of patients) }\end{array}$ & 47 \\
\hline Thyroid volume $\left(\mathrm{cm}^{3}\right)$ & $6,8 \pm 24,8(1,14-148,81)$ \\
\hline $\begin{array}{l}\text { Hypoparathyroidism after primary surgery } \\
\text { /second surgery }\end{array}$ & $5 / 4$ \\
\hline $\begin{array}{l}\text { Palsy of the recurrent laryngeal nerve after } \\
\text { primary surgery/second surgery }\end{array}$ & $3 / 3$ \\
\hline
\end{tabular}

Table 2. FNAB findings of patients with recurrent goiter.

\begin{tabular}{ll}
\hline Benign & $148(74 \%)$ \\
Suspicious & $6(2.71 \%)$ \\
Malign & $3(1.35 \%)$ \\
Inadequate & $52(26 \%)$ \\
Hurthle cell lesion & $5(2.26 \%)$ \\
Cellular microfollicular lesion & $7(3.16 \%)$ \\
Total & $221(100 \%)$ \\
\hline
\end{tabular}

Table 3. The pathological results of second surgery.

\begin{tabular}{ll}
\hline Malign & $4(22 \%)$ \\
Nodular Hyperplasia (NH) & $10(55 \%)$ \\
NH + Hashimoto Thyroiditis & $3(16.6 \%)$ \\
Hashimoto Thyroiditis & $1(5.5 \%)$ \\
Total & $18(100 \%)$ \\
\hline
\end{tabular}

\section{DISCUSSION}

Goiter affects $5-7 \%$ of the world's population, and in Turkey the prevalence varies widely from $5-56 \%$ (12-14). Between 10 and $15 \%$ of all goiter patients were operated at one time for thyroid, and the operations of recurrent goiter make up $12 \%$ of all thyroid operations (3-5). The main causes of recurrent goiter are the inadequacy of surgical extensiveness (15-18) and inadequacy of levothyroxine replacement (19-21). The nodules of recurrent goiter were found to be polyclonal and have growth potential in response to hypothalamo-hypophyseal thyroid axis, IGF-1 and increased IGF-1 binding protein expression (22-24). 
The remnant mass after thyroidectomy has the structural and functional features of the pathological tissue and that tissue is no longer under the control of classical hypothalamo-hypophysial thyroid pathway (25). Some surgeons suggest that it is impossible to prevent recurrence of benign multinodular goiter no matter which prophylaxis method is applied (26). On the contrary, there are some studies that demonstrated a recurrence risk of $14.3 \%$ after the subtotal thyroidectomy despite prophylaxis and a risk of $43 \%$ without a suppressive therapy $(25,27)$. In our study, $41.2 \%$ of the 114 patients with a recurrent goiter were receiving levothyroxine therapy.

Bononi et al. recommend total thyroidectomy as the best way to prevent recurrent goiter. The complication rate is no greater in total thyroidectomy than subtotal thyroidectomy for experienced surgeons (28). Piranneo and colleagues found a $39 \%$ recurrence in enucleation, $27 \%$ in lobectomy, $20 \%$ in lobectomy and contralateral enucleation and $4 \%$ in subtotal thyroidectomy. In another study, recurrences after subtotal thyroidectomy were shown to reach $14 \%$ (25). Second, thyroidectomy has an increased risk of complications such as paralysis of recurrent laryngeal nerve and hypoparahyroidism in comparison with primary surgery. In a study of 76 recurrent goiter patients with reoperation, 1 patient had bilateral recurrent nerve palsy requiring entubation, 1 had recurrent nerve palsy and $47.3 \%$ had transient hypoparathyroidism (29). In another study, complications in reoperative surgery were found to be greater than in first surgeries, and the complications of reoperative surgery were transient morbidities $8 \%$ (hypoparathyroidism $5 \%$, recurrent nerve palsy $1.2 \%$, hematoma $0.95 \%$ and wound infection $0.2 \%)$ and permanent morbidities $3.8 \%$ (1.5\% recurrent nerve palsy, $2.5 \%$ hypoparathyroidism) (30). In our study, 7\% (8 in 114 recurrent goiters) of patients experienced permanent complications (5 hypoparathyroidism and 3 recurrent nerve palsy) after first surgery and $38 \%$ (7 patients of 18 recurrent goiters with reoperation) experienced permanent complications ( 4 hypoparathyroidism and 3 recurrent nerve palsy) after second surgery.

The scar tissue of primary surgery makes it more difficult to avoid injury to recurrent laryngeal nerve or the vascular pedicle of the parathyroid gland. The complication risk of second surgery depends on primary surgery; either subtotal thyroidectomy or unilateral lobectomy and also extend of the recurrent disease, the proximity of the disease to recurrent laryngeal nerve, indications for which reoperative surgery is performed $(30,31)$. In our study, the permanent complication rate of second surgery was higher than other studies. It may be due to high percentage of the patient's primary surgery was subtotal thyroidectomy. Compared with primary surgery there were more permanent morbidities in second surgery; so, in order to prevent recurrences, total thyroidectomy is the best choice for primary surgery of benign multinodular goiter $(32,33)$.

The malignancy rate of recurrent goiter has been evaluated in various studies. Meneqaux and colleagues showed a malignancy rate of $11.1 \%$ (19 of 169), 5 cases with cervical node invasion (26.3\%) and 4 with visceral metastases (21.1\%) (34). A similar malignancy rate of $10 \%$ (42 of 418 patients) was found in patients with recurrent euthyroid nodular disease (30). In our study, 4 of 114 recurrent goiter patients had thyroid cancer, 2 with thyroid papillary carcinoma and 2 with thyroid papillary microcarcinoma. The dissonance of malignancy rate as compared to the literature may be due to the fact that 6 patients who were recommended for surgery did not accept reoperation surgery.

\section{CONCLUSION}

Benign multinodular goiter is one of the most common endocrine surgical problems. The appropriate surgical procedure for its effective and safe management is a matter of debate. In our study, we found that a high rate of recurrent goiter patients required reoperation and that there was a considerable complication rate in reoperative thyroid surgery. To eliminate the potential risk of reoperation, we recommend a total thyroidectomy instead of subtotal thyroidectomy or lobectomy as the surgery of choice for the primary surgery with benign indications.

\section{Conflict of interest}

No conflict of interest was declared by the authors

\section{REFERENCES}

1. Chen H, Dudley N, Westra W, Sadler G, Udelsman R. Utilization of fine-needle aspiration in patients undergoing thyroidectomy at two academic centers across the Atlantic. World J Surg. 2003; 27: 208-11.

2. Lang $\mathrm{BHH}$, Lo $\mathrm{CY}$. Total thyroidectomy for multinodular goiter in the elderly. Am J Surg. 2005; 190: 418-23.
3. Torre G, Barreca A, Borgonovo G, Minuto M, Ansaldo GL, Varaldo $\mathrm{E}$, et al. Goiter recurrence in patients submitted to thyroidstimulating hormone suppression: possible role of insulin-like growth factors and insulin-like growth factor-binding proteins. Surgery. 2000, 127: 99-103.

4. Kraimps JL, Marechaud R, Gineste D, Fieuzal S, Metaye T, Carretier $\mathrm{M}$, et al. Analysis and prevention of recurrent goiter. Surg Gynecol Obstet. 1993; 176: 319-322

5. Seiler CA, Glaser C, Wagner HE. Thyroid gland surgery in an endemic region. World J Surg. 1996; 20: 593-6.

6. Agarwal G, Aggarwal V. Is total thyroidectomy the surgical procedure of choice for benign multinodular goiter? An evidencebased review. World J Surg. 2008; 32:1313-24.

7. Moalem J, Suh I, Duh QY. Treatment and prevention of recurrence of multinodular goiter: an evidence-based review of the literature. World J Surg. 2008; 32: 1301-12.

8. Vasica G, O'Neill CJ, Sidhu SB, Sywak MS, Reeve TS, Delbridge LW. Reoperative surgery for bilateral multinodular goiter in the era of total thyroidectomy. Br J Surg. 2012; 99:688-92.

9. Schmitz-Winnenthal $\mathrm{FH}$, Schimmack $\mathrm{S}$, Lawrence $B$, Maier $U$, Heidmann $M$, et al. Quality of life is not influenced by the extent of surgery in patients with benign goiter. Langenbecks Arch Surg. 2011; 396:1157-63.

10. Ozbas S, Kocak S, Aydintug S, Cakmak A, Demirkiran MA, Wishart GC. Comparison of the complications of subtotal, near total and total thyroidectomy in the surgical management of multinodular goiter. Endocr J. 2005; 52: 199-205.

11. Bauer PS, Murray S, Clark N, Pontes DS, Sippel RS, Chen H. Unilateral thyroidectomy for the treatment of benign multinodular goiter. J Surg Res. 2013; 184: 514-8.

12. Gaitan E, Nelson NC, Poole GV. Endemic goiter and endemic thyroid disorders. World J Surg. 1991; 5: 205-15.

13. Muller PE, Jakoby R, Heinert G, Spelsberg F. Surgery for recurrent goitre: its complications and their risk factors. Eur J Surg. 2001; 167: 816-21.

14. Erdogan $G$, Erdogan MF, Emral R, Baştemir $M$, Sav $H$, Haznedaroğlu $D$, et al. lodine status and goiter prevalence in Turkey before mandatory iodization. J Endocrinol Invest. 2002; 25: 224-8.

15. Müller PE, Kabus S, Robens E, Spelsberg F. Indications, Risks, and Acceptance of Total Thyroidectomy for Multinodular Benign Goiter. Surg Today. 2001; 3: 958-62.

16. Korun N, Asci C, Yilmazlar T, Duman H, Zorluoglu A, Tuncel E, et al. Total thyroidectomy or lobectomy in benign nodular disease of the thyroid: changing trends in surgery. Int Surg. 1997; 82: 417-9.

17. Pappalardo G, Guadalaxara A, Frattaroli FM, Illomei G, Falaschi P. Total compared with subtotal thyroidectomy in benign nodular disease: personal series and review of published reports. Eur J Surg. 1998; 164: 501-6.

18. Liu Q, Djuricin G, Prinz RA. Total thyroidectomy for benign thyroid disease. Surgery. 1998; 123: 2-7.

19. Fritzsche H. Die resezierte Struma: Diagnose, Rezidivprophylaxe, Therapie. Acta Med Austr. 1982; 34: 33-8.

20. Goretzki P, Roecher HD, Horeyseck G. Prophylaxis of recurrent goiter by high dose L - tyroxine. World J Surg. 1981; 5: 855-7.

21. Kologlu S, Bascal N, Kologlu LB. The value of L-thyroxine in the suppressive therapy of euthyroid nodules and in the prevention of post thyroidectomy recurrences. Rom J Med. 1988; 26: 89-98.

22. Torre G, Barreca A, Borgonovo G, Minuto $M$, Ansaldo GL, Varaldo $E$, et al. Goiter recurrence in patients submitted to thyroidstimulating hormone suppression: possible role of insulin-like growth factors and insulin-like growth factor-binding proteins. Surgery. 2000; 127: 99-103.

23. Harrer $P$, Broecker $M$, Zint $A$, Schatz $H$, Zumtobel V, Derwahl $M$. Thyroid nodules in recurrent multinodular goiters are predominantly polyclonal. J Endocrinol Invest. 1998; 21: 380-5.

24. Studer H, Derwahl M. Mechanism of non-neoplastic endocrine hyperplasia - a changing concept: a review focused on the thyroid gland. Endocr Rev. 1995; 16: 411-26.

25. Piraneo S, Vitri $P$, Galimberti A, Guzzetti S, Salvaggio A, Bastagli A. Recurrence of goiter after operation in euthyroid patients. Eur J Surg. 1994; 160: 351-6.

26. Kraimps JL, Marechaud R, Gineste D, Fieuzal S, Metaye T, Carretier $\mathrm{M}$, et al. Analysis and prevention of recurrent goiter. Surg Gynecol Obstet. 1993; 176: 319-22. 
27. Pappalardo G, Guadalaxara A, Frattaroli FM, Illomei G, Falaschi P. Total compared with subtotal thyroidectomy in benign nodular disease: personal series and review of published reports. Eur J Surg. 1998; 164: 501-6.

28. Bononi M, de Cesare A, Atella F, Angelini M, Fierro A, Fiori E et al. Surgical treatment of multinodular goiter: incidence of lesions of the recurrent nerves after total thyroidectomy. Int Surg. 2000; 85: 190-3.

29. Pironi D, Panarese A, Candioli S, Manigrasso A, La Gioia G, Romani $A M$, et al. Reoperative thyroid surgery: personal experience and review of the literature. G Chir. 2008; 29: 407-12.
30. Lefevre JH, Trsallet C, Leenhardt L, Jublanc C, Chigot JP, Menegaux F. Reoperative surgery for thyroid disease. Surg. 2007; 392: 68591.

31. Shara AR.Revision thyroid surgery - technical considerations. Otolaryngol Clin North Am. 2008;41:1169-83.

32. Dener $C$. Complication rates after operations for benign thyroid disease. Acta Otolaryngol. 2002; 122: 679-83.

33. Colak T, Akca T, Kanik A, Yapici D, Aydin S. Total versus subtotal thyroidectomy for the management of benign mutlinodular goiter in an endemic region. ANZ J Surg. 2004; 74:974-8.

34. Meneqaux F, Leenhaedt L, Dahman M, Schmitt G, Aurengo A, Chigot JP. Repeated thyroid surgery, indications and results. Presse Med. 1997; 26: 1850-4. 